\title{
Ophiuroids (Echinodermata) of southern Chile and the Antarctic: Taxonomy, biomass, diet and growth of dominant species*
}

\author{
CORINNA DAHM \\ Alfred Wegener Institute for Polar and Marine Research, P.O. Box 120161, D-27515 Bremerhaven, Germany. \\ E-mail: cdahm@awi-bremerhaven.de
}

\begin{abstract}
SUMMARY: This study aims on a first comparison of the shallow water $(<550 \mathrm{~m})$ ophiuroid fauna of the Magellan region and the high-Antarctic Weddell Sea. Five species are common to both the Magellan region (22 species) and the Weddell Sea (42 species). The most abundant Magellan species is Ophiuroglypha lymani, contributing 33\% to total ophiuroid abundance and $44 \%$ to total ophiuroid biomass. The diets of $O$. lymani and of three closely related (same sub-family Ophiurinae) also dominant, Antarctic species are similar, indicate however slightly different feeding strategies. The Magellan species tends more towards microphageous grazing, whereas the Weddell Sea species act more like scavengers. Within the sub-family Ophiurinae growth performance of $O$. lymani is higher than in Antarctic species and in the range of boreal species.
\end{abstract}

Key words: Ophiuroids, biomass, diet, growth, age.

RESUMEN: OFIUROIDEOS DEL SUR DE CHILE Y DE LA ANTÁRTIDA: TAXONOMÍA, BIOMASA, ALIMENTACIÓN Y CRECIMIENTO DE LAS ESPECIES DOMINANTES. - El objetivo del presente estudio es realizar una primera comparación entre la fauna de ofiuroideos de aguas someras $(<550 \mathrm{~m})$ de la región de Magallanes y del Mar de Weddell (alta Antártida). Cinco de las especies estudiadas estan presentes tanto en la región de Magallanes (22 especies), como en el Mar de Weddell (42 especies). La especie magallánica más abundante es Ophiuroglypha lymani, contribuyendo en un 33-100\% a la abundancia numérica total de ofiuroideos y en un $44-100 \%$ a la biomasa total de los mismos. La dieta de $O$. lymani y de tres especies taxonómicamente próximas (pertenecientes a la misma subfamilia: Ophiurinae), también dominantes, en la Antártida son similares, aunque presentan algunas diferencias en sus estrategias de alimentación. La especie magallánica tiende más hacia estrategias de tipo ramoneador micrófago, mientras que las especies del Mar de Weddell actúan más como carroñeros. Dentro de la subfamilia Ophiurinae, el crecimiento de $O$. lymani es mayor en comparación con el de las especies antárticas y está dentro del rango de las especies boreales.

Palabras clave: Ofiuroideos, biomasa, dieta, crecimiento, edad.

\section{INTRODUCTION}

World-wide there are about 1600 existing species of ophiuroids; this class surpasses all other classes of echinoderms in number of surviving species, except asteroids. In many benthic communities of

This is AWI publication no. 1481

*Accepted October 15, 1998. the world oceans ophiuroids contribute significantly to species diversity, abundance and biomass of the fauna (see e.g. Hyman, 1955; Fell et al., 1969; Tyler, 1980; Barnes, 1987; Voß, 1988; Gerdes et al., 1992; Dahm, 1996).

Echinoderms, and especially ophiuroids, are very common on either side of the Drake Passage (Larraín, 1995) and also in the high Antarctic (Voß, 1988; Dahm, 1996). This paper is a first attempt to 
compare the Magellan and high Antarctic ophiuroid fauna. I will address the following questions:

1. How similar are the Magellan and the high Antarctic ophiuroid fauna from a taxonomic point of view?

2. How do ophiuroids contribute to total macrozoobenthos biomass in these regions?

3 . Is the diet of the dominant species from the Magellan region comparable to the diet of closely related as well as dominant species from the Antarctic? 4. Are there differences in growth and age between closely related species from these regions?

\section{MATERIAL AND METHODS}

\section{Investigation area, sampling and preservation}

In the Magellan region (Fig. 1) 47 Agassiz trawl samples (max. depth $350 \mathrm{~m}$ ) were taken during the Joint Chilean-German-Italian Magellan Campaign in 1994 by RV "Victor Hensen" and during the expedition ANT XIII/4 of RV "Polarstern" in 1996. Stations, investigation area and sample treatment are described in Arntz and Gorny (1996) and Fahrbach and Gerdes (1997). In the Weddell Sea (Fig. 1) 117 trawl samples were taken during seven expeditions of RV "Polarstern" between 1983 and 1992 (Dahm, 1996; max. depth $550 \mathrm{~m}$ ). All samples were fixed in $4 \%$ formaldehyde buffered with hexamethylentetramine. In the laboratory all individuals were identified to species and then stored in $70 \%$ ethanol.

\section{Estimation of biomass}

Ophiuroid biomass was computed from multibox corer samples taken by Gerdes et al. (1992) in the Weddell Sea (see Dahm, 1996) and by Gerdes (1999) in the Magellan region.

\section{Stomach content analysis}

The ophiuroid disc was cut around the perimeter and the aboral surface removed to expose the stomach. Contents were examined microscopically and food items identified as exactly as possible. Ophiuroid diet was quantified using a points method (Swynnerton and Worthington, 1940; Hynes, 1950) modified by Brun (1972) and Dearborn et al. (1986) which combines information on stomach fullness and volumetric contribution of food items (for fur-

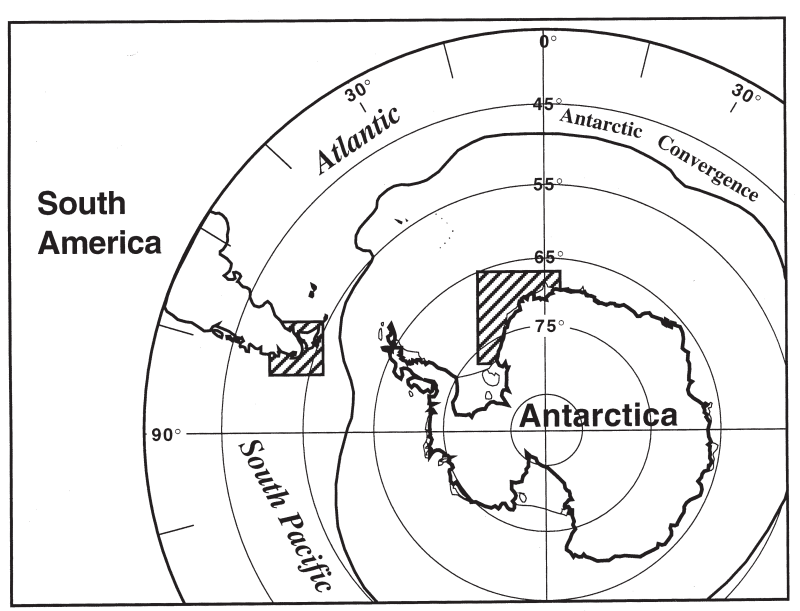

FIG. 1. - Sampling areas in the Magellan region and the Weddell Sea.

ther details see Fratt and Dearborn, 1984; Dearborn et al., 1986; Dahm, 1996; Dahm and Brey, subm.).

\section{Growth and age}

Age of ophiuroids was determined by analyzing the microstructure of annually formed growth rings on the vertebral ossicles of the arms according to Dahm (1993, 1996), Dahm and Brey (1998) and Gage (1990a). I use the Richards function to model individual growth:

$$
\mathrm{S}_{\mathrm{t}}=\mathrm{S}_{\infty}\left(1-\mathrm{D} \cdot \mathrm{e}^{-\mathrm{K}(\mathrm{t}-\mathrm{to})}\right)^{(1 / \mathrm{D})}
$$

where $\mathrm{S}_{\infty}$ is asymptotic size, $\mathrm{K}\left(\mathrm{y}^{-1}\right)$ is the growth constant, $\mathrm{D}$ is a shaping parameter and $\mathrm{t}_{\mathrm{o}}(\mathrm{y})$ determines the inflexion point of the curve. Growth performance was computed according to Brey (in press):

$$
\varphi=\log \left(\mathrm{M}_{\max } / \mathrm{A}_{\max }\right)
$$

where $\mathrm{M}_{\max }$ is maximum body mass $(\mathrm{kJ})$ and $\mathrm{A}_{\max }$ is maximum age (y).

\section{RESULTS}

\section{Taxonomic similarity}

In the Magellan region 22 species were found (15 of these identified to the species) belonging to 14 genera and 7 families in comparison to 42 species belonging to 21 genera and 6 families in the Weddell Sea. 5 species, 6 genera and 4 families are common to both regions (Table 1). 
TABLE 1. - Ophiuroid species found in the Weddell Sea (Antarctica; Dahm, 1996) and in the Magellan region. Note that seven further Magellan species could not be identified to the species and are hence not included in this table.

\begin{tabular}{|c|c|c|}
\hline Species & $\begin{array}{c}\text { Weddell } \\
\text { Sea }\end{array}$ & $\begin{array}{c}\text { Magellan } \\
\text { Region }\end{array}$ \\
\hline
\end{tabular}

Gorgonocephalidae:

Astrotoma agassizii Lyman, 1875

Astrochlamys bruneus Koehler, 1912

Astrochlamys sol Mortensen, 1936

Astrohamma tuberculatum (Koehler, 1923)

Gorgonocephalus chilensis (Philippi, 1858)

Ophiacanthidae:

Ophiacantha pentactis Mortensen, 1936

Ophiacantha antarctica Koehler, 1901

Ophiacantha vivipara Ljungman, 1870

Ophiacantha frigida Koehler, 1908

Ophiacantha cosmica Lyman, 1878

Ophiosparte gigas Koehler, 1922

Ophiomitrella falklandica Mortensen, 1936

Ophiacamax gigas Koehler, 1901

Amphiuridae:

Amphiura proposita Koehler, 1922

Amphiura protecta Hertz, 1927

Amphiura lymani Studer, 1885

Amphiura algida Koehler, 1911

Amphiura belgicae Koehler, 1901

Amphiura eugeniae Ljungman, 1867

Amphiura deficiens Koehler, 1922

Amphiura microplax disjuncta Mortensen, 1936

Amphiura dilatata gaussi Hertz, 1927

Ophioleucidae:

Ophioleuce regulare (Koehler, 1901)

Ophiuridae:

Ophioceres incipiens Koehler, 1922

Glaciacantha dubium (Koehler, 1901)

Glaciacantha döderleini (Hertz, 1927)

Ophiocten dubium Koehler, 1901

Ophiocten megaloplax (Koehler, 1901)

Ophiocten amitinum Lyman, 1878

Ophiuroglypha lymani (Ljungman, 1870)

Ophionotus victoriae Bell, 1902

Ophioperla koehleri (Bell, 1908)

Ophiosteira echinulata Koehler, 1922

Ophiosteira debitor Koehler, 1922

Ophiosteira rotundata Koehler, 1922

Ophiosteira senouqui Koehler, 1901

Ophiurolepis brevirima Mortensen, 1936

Ophiurolepis gelida (Koehler, 1901)

Ophiurolepis martensi (Studer, 1885)

Ophiurolepis tumescens Koehler,1922

Ophiogona döderleini (Koehler, 1901)

Ophiura rouchi (Koehler, 1912)

Ophiura serrata Mortensen, 1936

Ophiura ambigua (Lyman, 1878)

Homalophiura inornata (Lyman, 1882)

Theodoria relegata (Koehler, 1922)

Ophiozonella falklandica Mortensen, 1936

Hemieuryalidae:

Ophiochondrus stelliger Lyman, 1879

Ophiactidae:

Ophiactis asperula (Philippi, 1858)

Ophiomyxidae:

Ophioscolex nutrix Mortensen, 1936

Ophiomyxa vivipara Studer, 1876

Ophiodermatidae:

Toporkovia antarctica (Lyman, 1882)

Total:

42

\section{Biomass}

According to the data of Gerdes (1999) and Gerdes et al. (1992) ophiuroids contribute $1 \%(=0.07$ $\mathrm{gC}_{\text {org }} \mathrm{m}^{-2}$ ) to total macrozoobenthos biomass in the Magellan region and about $4 \%\left(=0.44 \mathrm{gC}_{\text {org }} \mathrm{m}^{-2}\right)$ in the Weddell Sea. Taking into account a correction necessary for underestimation of ophiuroid biomass by corers (Dahm, 1996), true biomass is about $3 \%$ of macrobenthic biomass in the Magellan region and $12 \%$ in the Weddell Sea, respectively.

\section{Diet}

Diet was compared within the sub-family Ophiurinae which includes the dominant ophiuroids of both regions, Ophiuroglypha lymani in the Magellan region and Ophionotus victoriae, Ophiurolepis geli$d a$ and Ophiurolepis brevirima in the Weddell Sea (see Dahm, 1996). Figure 2 shows the diet composition of $O$. lymani after the first phytoplankton bloom and subsequent sedimentation event of the year. The species is omnivorous and feeds mainly on crustaceans $(25 \%)$, sediment (25\%) and phytodetritus (23\%). The three Antarctic species feed on the same range of items shown in Figure 2, but their diet contains distinctly more crustaceans (about 47\%), less phytodetritus (about 12\%) and occasionally polychaetes and sponge needles (Dahm, 1996).

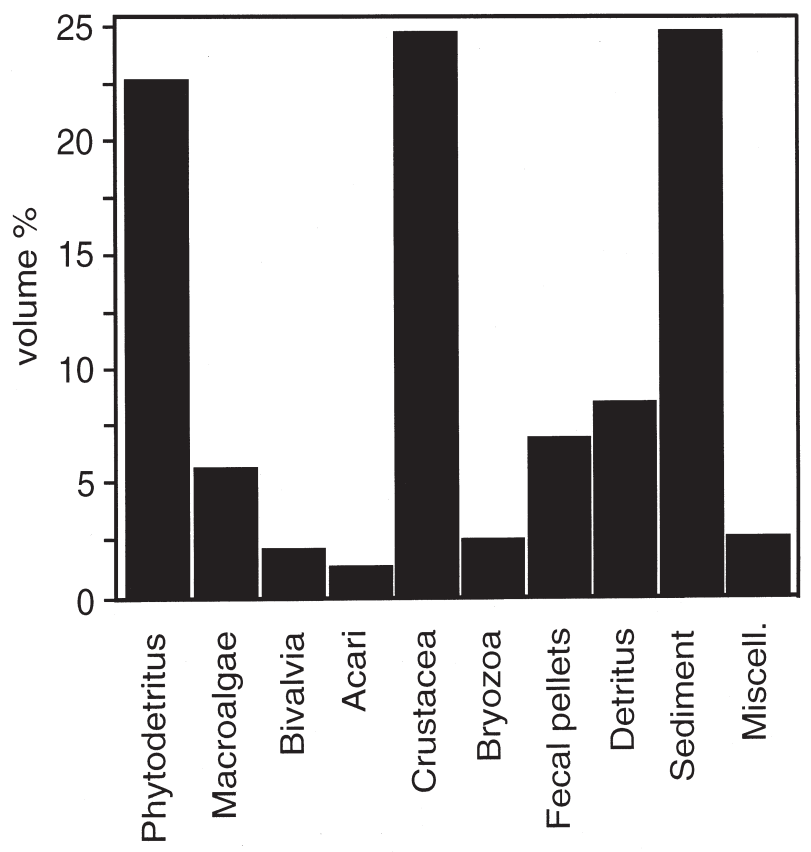

FIG. 2. - Diet composition of $O$. lymani in the Magellan region (Beagle Channel, 200 - $350 \mathrm{~m}$ water depth, $\mathrm{N}=63$ ) in summer. 


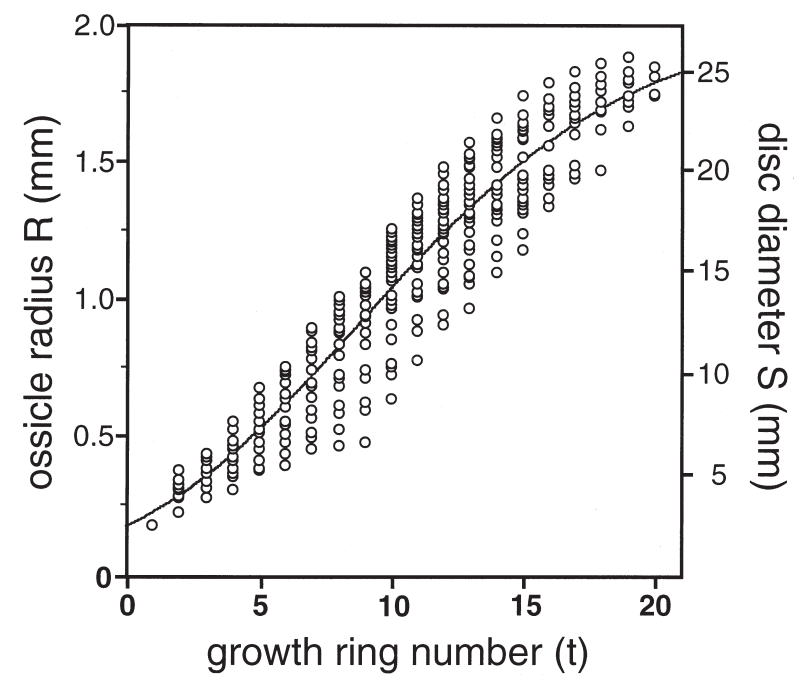

FIG. 3. - Growth of ossicle radius $\mathrm{R}$ and disk diameter $\mathrm{S}$ of $O$. lymani in the Magellan region. Richards growth function fitted to size-at-age data obtained from ossicle growth band readings (320 band readings from 42 individuals). Growth parameters: $\mathrm{R}_{\infty}=2.1 \mathrm{~mm} ; \mathrm{K}=0.17 ; \mathrm{t}_{\mathrm{o}}=8.58 ; \mathrm{D}=0.41$

\section{Age and growth}

Figure 3 shows the growth curve of $O$. lymani in the Beagle Channel fitted to size-at-age data obtained from ossicle readings. The oldest specimens of $O$. lymani were 20 years old with a disc diameter of about $25 \mathrm{~mm}$. For the three Antarctic species, Dahm (1996) determined maximum age and disc diameter to be 22 years and $32 \mathrm{~mm}$ for $O$. victoriae, 33 years and $21 \mathrm{~mm}$ for Ophiurolepis gelida and 25 years and $21 \mathrm{~mm}$ for Ophiurolepis brevirima. Growth performance of the Magellan species $O$. lymani is higher than that of the three Antarctic species but in the range of boreal species (Fig. 4).

\section{DISCUSSION}

Ophiuroids can tolerate a wide depth as well as temperature range (e.g. Brey et al., 1996). Therefore we should expect many Antarctic species to occur outside the South Polar Sea (South America or New Zealand). As shown here (Table 1), five high Antarctic (Weddell Sea) species are present in South America, whereas New Zealand and Antarctica have only one species in common (Fell et al., 1969). The range of many shelf and slope ophiuroid species is controlled by depth, hence only the existence of shallow water routes allows wider dispersal (Fell et

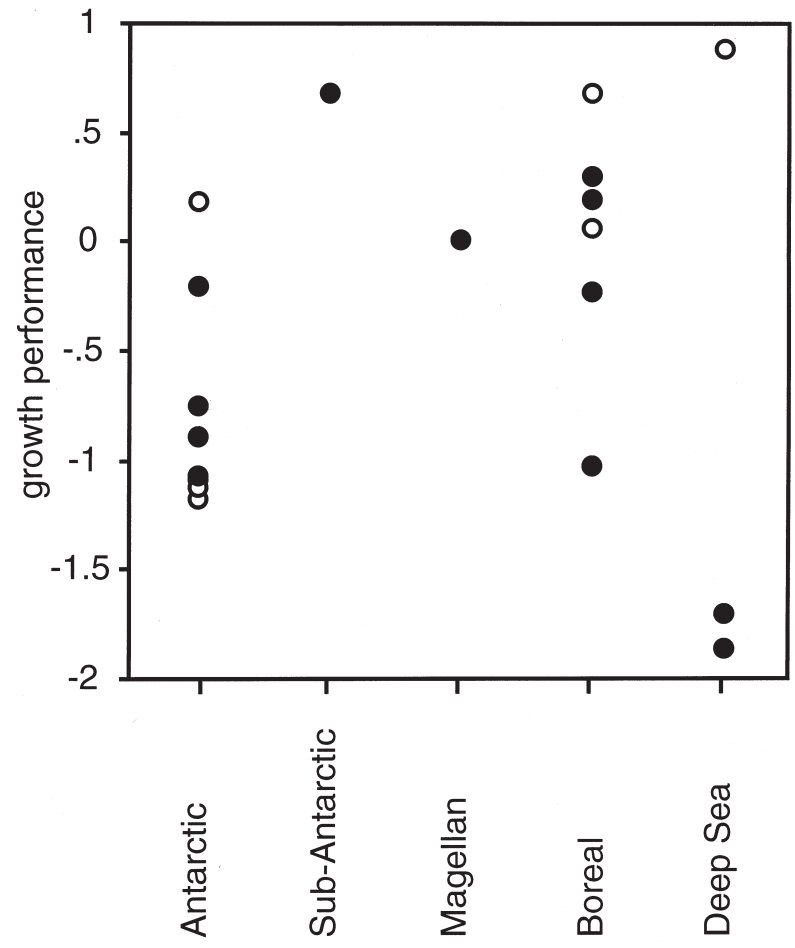

FIG. 4. - Growth performance $\left(\varphi=\log \left(\mathrm{M}_{\max } / \mathrm{A}_{\max }\right)\right)$ of ophiuroids from various regions. Dots: Species belonging to the sub-family Ophiurinae. Circles: Species belonging to other taxa. Data sources: Antarctic: Dahm (1996); sub-Antarctic: Morison (1979); Magellan: this study; Boreal: Dahm (1993), Munday and Keegan (1992); Warwick et al. (1978), Warwick and George (1980); George and Warwick (1985); Deep Sea: Gage (1990b), Gage and Tyler (1981, 1982a, b).

al., 1969). No such shallow water route existed in the more recent history between New Zealand and Antarctica, whereas there is a submerged ridge, the Scotia Arc, between the Antarctic Peninsula and South America (Fell et al., 1969). This is the most likely migration route for eurybathic species and may explain the higher number of common species. However, there are no fossil records which might indicate the direction or time scale of this migration (Arntz et al., 1994).

\section{Species numbers and biomass}

In terms of species numbers and biomass, ophiuroids play a less significant role in the Magellan region ( 22 species, $3 \%$ of biomass) than in the Weddell Sea (42 species, $12 \%$ of biomass). The strong presence of ophiuroids in environments with low and highly seasonal food input such as polar seas or many deep sea regions indicates special adaptations and higher competitiveness of ophiuroids under those conditions. Consequently, the lower biomass of ophiuroids in the Magellan region may be related 
to more favourable conditions for the benthic fauna. Longer periods of food availability may enable other taxa to compete better against ophiuroids. It should be noted, however, that certain boreal benthic communities may be dominated by ophiuroids, too, as observed by George and Warwick (1985) or O'Connor et al. (1986).

\section{Diet, age and growth}

It might have been more meaningful to compare diet and growth of the same species in the Magellan region and in the Weddell Sea, however, none of the species encountered occurred in sufficient numbers in both regions.

The diet of all four species of Ophiurinae analysed here is basically similar (crustaceans, phytodetritus, sediment), but nonetheless indicates differences in feeding strategy between the Magellan and Antarctic species. The Magellan species $O$. lymani contains comparatively more phytodetritus and sediment, indicating some kind of microphageous "grazing" strategy (Warner, 1982). The higher amount of crustaceans ingested by the Antarctic species, $47 \%$ compared to $25 \%$ in $O$. lymani, indicates that these species act more like scavengers, which ingest phytodetritus and sediment either accidentally or as a second choice food (Warner, 1982). This difference may indicate that competition for the principal food source of benthic animals, i.e. sedimented matter, is higher in the Antarctic, forcing the dominant ophiuroid species to vertically expand their trophic niche (see Dahm, 1996).

With only one Magellan ophiuroid species analyzed so far (Fig. 3), I am not able to make solid general statements about growth and growth performance. My data, however, indicate that Antarctic species show lower growth performance than closely related species from the Magellan area or other more northerly regions (Fig. 4). This is in accordance with previous comparisons based on data referring to various benthic taxa from Antarctic and non-Antarctic regions (Arntz et al., 1994).

\section{REFERENCES}

Arntz, W.E., T. Brey and V.A. Gallardo. - 1994. Antarctic zoobenthos. Oceanogr. Mar. Biol. Ann. Rev., 32: 241-304.

Arntz, W.E. and M. Gorny. - 1996. Cruise report of the Joint Chilean-German-Italian Magellan "Victor Hensen" Campaign in 1994. Ber. Polarforsch., 190: 1-113.

Barnes, R.D. - 1987. Invertebrate Zoology. Saunders College Publ., Philadelphia.
Brey, T., C. Dahm, M. Gorny, M. Klages, M. Stiller and W.E. Arntz. - 1996. Do Antarctic benthic invertebrates show an extended level of eurybathy? Antarct. Sci., 8: 3-6.

Brey, T. - 1999. Growth performance and mortality in macrobenthic invertebrates. Adv. Mar. Biol.

Brun, E. - 1972. Food and feeding habits of Luidia ciliaris Echinodermata: Asteroidea. J. Mar. Biol. Ass. U.K., 52: 225-236.

Dahm, C. - 1993. Growth, production and ecological significance of Ophiura albida and O. ophiura (Echinodermata: Ophiuroidea) in the German Bight. Mar. Biol., 116: 431-437.

Dahm, C. - 1996. Okologie und Populationsdynamik antarktischer Ophiuroiden (Echinodermata). Ber. Polarforsch., 194: 1-289.

Dahm, C. and T. Brey. - 1998. How to determine growth and age of slow growing brittle stars (Echinodermata: Ophiuroidea) from natural growth bands. J. mar. biol. Ass. U.K., 78: 941-951.

Dahm, C. and T. Brey. - subm. Energy flow through Antarctic ophiuroids (Echinodermata) inhabiting the Weddell Sea: Part I: Abundance, biomass and food. Antarct. Sci.

Dearborn, J.H., F.D. Ferrari and K.C. Edwards. - 1986. Can pelagic aggregations cause benthic satiation? Feeding biology of the Antarctic brittle star Astrotoma agassizii (Echinodermata: Ophiuroidea). Ant. Res. Ser., 44 (Biology of the Antarctic Seas XVII): 1-28.

Fahrbach, E. and D. Gerdes. - 1997. Die Expedition ANTARKTIS XIII/4-5 des Forschungsschiffes "Polarstern" 1996. Ber. Polarforsch., 239: 1-126.

Fell, H.B., T. Holzinger and M. Sherraden. - 1969. Ophiuroidea. Antarct. Map Folio Ser., 11: 42-43.

Fratt, D.B. and J.H. Dearborn. - 1984. Feeding biology of the Antarctic brittle star Ophionotus victoriae (Echinodermata: Ophiuroidea). Polar Biol., 3: 127-139.

Gage, J.D. - 1990a. Skeletal growth bands in brittle stars: microstructure and significance as age markers. J. Mar. Biol. Ass. U.K., 70: 209-224

Gage, J.D. - 1990b. Skeletal growth markers in the deep-sea brittle stars Ophiura ljungmani and Ophiomusium lymani. Mar. Biol., 104: 427-435.

Gage, J.D. and P.A. Tyler. - 1981. Re-appraisal of age composition, growth and survivorship of the deep-sea brittle star Ophiura ljungmani from size structure in a sample time series from the Rockall Trough. Mar. Biol., 64: 163-172.

Gage, J.D. and P.A. Tyler. - 1982a. Depth-related gradients in size structure and the bathymetric zonation of deep-sea brittle Mar. Biol., 71: 299-308.

Gage, J.D. and P.A. Tyler. - 1982b. Growth and reproduction of the deep-sea brittle star Ophimusium lymani Wyville Thomson. Oceanol. Acta, 5: 73-83.

George, C.L. and R.M. Warwick 1985. Annual macrofauna production in a hard-bottom reef community. J. Mar. Biol. Ass. U.K., 65: 713-735.

Gerdes, D., M. Klages, W.E. Arntz, R.L. Herman, J. Galéron and S. Hain. - 1992. Quantitative investigations on macrobenthos communities of the southeastern Weddell Sea shelf based on multibox corer samples. Polar Biol., 12: 291-301.

Hyman, L.H. - 1955. Echinodermata. Vol.4. The Invertebrates. McGraw-Hill, New York.

Hynes, H.B.N. - 1950. The food of fresh-water sticklebacks (Gasterosteus aculeatus and Pygosteus pungitius), with a review of methods used in studies of the food of fishes. J. Anim. Ecol., 19: 36-58.

Larraín, A.P. - 1995. Biodiversidad de equinodermos chilenos: estado actual del conocimiento y sinopsis biosistemática. Gayana Zool., 59: 73-96.

Morison, G.W. - 1979. Studies on the ecology of the Subantarctic ophiuroid Ophionotus hexactis. M. Phil. Thesis, Univ. London.

Munday, B.W. and B.F. Keegan. - 1992. Population dynamics of Amphuira chiajei (Echinodermata: Ophiuroidea) in Killary Harbour, on the west coast of Ireland. Mar. Biol., 114: 595-605.

O'Connor, B., T. Bouwmer, D. McGrath and R. Raine. - 1986. Energy flow through an Amphiura filiformis (Ophiuroidea: Echinodermata) population in Galway Bay, west coast of Ireland: a preliminary investigation. Ophelia, 26: 351-357.

Swynnerton, G.H. and E.B. Worthington. - 1940. Note on the food of fish in Haweswater (Westmorland). J. Anim. Ecol., 9: 183187.

Tyler, P.A. - 1980. Deep-sea ophiuroids. Oceanogr. Mar. Biol. Ann. Rev., 18: 125-153.

Voß, J. - 1988. Zoogeographie und Gemeinschaftsanalyse des 
Makrozoobenthos des Weddellmeeres (Antarktis). Ber. Polarforsch., 45: 1-145.

Warner, G. - 1982. Food and feeding mechanisms: Ophiuroidea. In: M. Jangoux and J. M. Lawrence (eds): Echinoderm Nutrition, pp. 161-181. Balkema, Rotterdam.

Warwick, R.M. and C.L. George. - 1980. Annual macrofauna production in an Abra community. In: M. B. Collins, F. T. Banner,
P. A. Tyler, S. J. Wakefield and E. James (eds), Industrialized Embayments and their Environmental Problems, pp. 517-538. Pergamon, Oxford.

Warwick, R.M., C.L. George and J.R. Davies. - 1978. Annual macrofauna production in a Venus community. Estuar. Coastal Mar. Sci., 7: 215-241. 